уДК $342.72 / .73$

DOI https://doi.org/10.32837/apdp.v0i85.1874

А.О.Тарановська

\title{
КОНЦЕПТУАЛЬНІ ОСНОВИ ПРАВ І СВОБОД ЛЮДИНИ В ІУДЕЙСЬКОМУ ПРАВІ ТА ЇХ СУТНІСНІ РИСИ В КОНСТИТУЦІї УКРАЇНИ
}

Постановка проблеми. Питання визначення категорії «права людини» та їх захист на сьогодні є актуальним, популярним і вивчається провідними науковцями та юристами-практиками. Загальновідомо, що в юридичній науці та в міжнародно-правових актах відсутнє єдине визначення поняття «права людини», незважаючи на його гостру соціальну значущість. Необхідно зазначити, що на теоретичному рівні права людини розглядаються як загальні та рівні можливості для всіх людей без винятку.

Аналіз останніх досліджень і публікацій. Проблематика теорії прав людини в різний час перебувала в центрі уваги таких учених-правників: М. Кравчук, О. Скакун, П. Рабинович, С. Добрянський, Т. Ярошевська, В. Васецький, Н. Заінчковський, О. Пушкіна тощо. Права людини - це певні можливості, які необхідні кожному для існування та розвитку в конкретних історичних умовах, що об'єктивно визначаються досягнутим рівнем розвитку всього людства й мають бути загальними та рівними для всіх людей [2, с. 13].

Прийнято вважати, що розквіт формування концепції теорії прав людини прослідковується в епоху Просвітництва в роботах західноєвропейських філософів та мислителів. Категорію «права людини» в сучасному розумінні вперше розкрито у книзі «Права людини» Томаса Пейна, відомого як «хрещеного батька» США та ідеолога Американської революції, а також у статті Вільяма Ллойда Гаррісона, котрий заснував американську антирабовласницьку спільноту, в газеті «Ліберейтор» в XIX столітті. Офіційно поняття «права людини» вперше проголошено в Конституції Сполучених Штатів Америки у 1787 році.

Варто наголосити, що для того часу гострою й важливою темою був процес скасування рабства як неприпустимого явища в капіталістичному суспільстві.

Однак Друга світова війна розкрила людству об’єктивну політичну ситуацію щодо цінності та місця людини в державі. Необхідно звернути увагу, що саме після вищезгаданої світової трагедії в 1948 році прийнято Загальну декларацію прав людини. 3 огляду на досить тривалий шлях до цієї визначної події постає доречне запитання щодо того, чи «права людини» - це здобуток епохи Просвітництва, котрий закріпився в міжнародно-правових актах у XX столітті, чи, можливо, що вказана категорія має більш глибоке історичне коріння. Відповідно, II Розділ Конституції України «Права та свободи людини і громадянина» дублює на національному рівні норми вищевказаного міжнародно-правового акта.

Метою статті є виявити та охарактеризувати історичну генезу концепції теорії прав і свобод людини в аспекті зв'язку з релігійною доктриною іудаїзму та порівняти з нормами Конституції України як Основного Закону нашої держави. Для реалізації вказаної мети поставлено такі завдання:

(C) А. О. Тарановська, 2020 
- проаналізувати релігійні тексти іудейської релігійної традиції;

- проаналізувати норми Конституції України;

- порівняти їх сутнісні ознаки та функціональні зв'язки;

- узагальнити висновки щодо наявності або відсутності спільних норм і принципів у досліджуваних об'єктах.

Виклад основного матеріалу. Як відомо, поняття «права людини» не вживалось в античному світі взагалі, для рабовласницького суспільства не було прийнятно говорити про таке. Для тогочасної єврейської держави також був характерний рабовласницький устрій, проте господар не мав права вирішувати долю раба - жити або вмирати, він міг відпустити на волю, одружити тощо, але людське життя - це воля Бога. Характерною рисою стародавньої єврейської держави був міцний зв'язок із релігією, релігійні норми регулювали життя кожного єврея з моменту, коли він прокидався зранку, протягом усього дня і всього життя. Іудейське право є самобутнім та незалежним, закон у ньому є первинним, а держава і влада - вторинним. На нашу думку, це головна причина того, чому єврейський народ, перебуваючи під юрисдикцією неєврейської державності, зумів зберегти свою релігію, вчення, культуру, традиції, право тощо.

Російський науковець, Президент Фонду з вивчення громадянського суспільства й людського капіталу Р. Іліїв у статті «Іудаїзм та права людини» наполягає на тому, що процес розвитку концепції теорії прав людини бере початок від Десяти Божих Заповідей, отриманих Мойсеєм на горі Сінай, до прийняття Конституції Сполучених Штатів Америки у 1787 році та проголошення Загальної декларації прав людини 10 жовтня 1948 року. Він зазначає, що іудаїзм - це перша релігія, котра закріпила універсальні норми моралі, які формували поведінку людини на буденному рівні, поєднуючи загальні та індивідуальні принципи [3].

Крім того, іудейське (єврейське) право є унікальним здобутком людської цивілізації, однією з найдавніших правових систем світу релігійного типу та регулює суспільні відносини всередині єврейської общини, котра сповідує іудаїзм. Історія єврейського права налічує більше п'яти тисячоліть і не втрачає актуальність дотепер. Особливої уваги заслуговує той факт, що єврейський народ зміг зберегти свою ідентичність в умовах тривалого періоду (понад два тисячоліття) бездержавності та гонінь.

Як зазначено, іудейське право засновано на релігійних доктринах іудаїзму. Узагалі, іудаїзм - це стародавня етнічна та монотеїстична релігія, котра зародилась на території Близького Сходу.

У зв'язку з вищевикладеним іудаїзм як одна зі світових релігій має власне Святе Письмо - це Танах, який закріплює не лише історію та мудрість єврейського народу, але й етичні норми та правила поведінки, котрі заповідав Бог, і складається з таких частин:

- Тора (П’ятикнижжя Мойсея, що і собі містить: Книга Буття (Берешит), Книга Вихід (Шмот), Книга Левіт (Ваїкра), Книга Числа (Бемідбар), Книга Второзаконня, Повторення Закону (Дварим);

- Невіїм ( Книга Пророки);

- Ктувім (Писання). 
Іудейська релігійна доктрина - це потужна система принципів, норм та приписів, котрі виступають універсальними суспільними регуляторами та мають чітку ієрархію, звичайно, надважлива роль належить Торі. Однак не варто забувати про праці авторитетних рабинів, наприклад, про кодекс Рамбама Мішне Тора (1135-204 рр.), «Шулхан Арух» рабі Йосефа Каро, датований 1563 р. тощо.

Отже, відповідно до порівняльного аналізу Священного Писання іудаїзму та Конституції України від 28.06.1996 року, а саме Розділ II «Права, свободи та обов'язки людини і громадянина», маємо такі характерні ознаки:

1. Згідно зі статтею 27 Конституції України кожна людина має невід’ємне право на життя, звертаємось до Глави 21:12-15 Книги Вихід (Книга Шмот), котра закріплює таку норму: «хто вдарить людину так, що вона загине, да буде йому смерть», але якщо не було наміру вбити, але людина померла, то вбивці надається місце, куди втекти. Шоста Божа Заповідь також містить заборону вбивства людини.

2. Право на життя засноване на унікальності кожної людини, адже в іудаїзмі Бог створив чоловіка згідно з образом Авраама, проте немає двох однакових людей - усі абсолютно різні. Людина - це вінець творіння Господа, велична істота, яка подібна до Бога. Лише вона може надавати навколишнім явищам, процесам й об’єктам особливий духовний сенс. Якщо одна людина завдає шкоду іншій - це злочин проти Всевишнього.

3. «А хто вдарить батька свого чи матір свою, той конче буде забитий», - Книга Вихід (Шмот) (21:15). П’ята Заповідь Божа закріплює норму щодо вшанування батьків.

Отже, відповідно до вищевикладеного, життя тогочасної людини в іудаїзмі мало сакральне значення.

4. «Люби ближнього свого, як самого себе», - так учить Свята книга єврейського народу Тора (П'ятикнижжя Мойсея), одна з головних ідей іудаїзму, котра згодом закріпилась і у християнстві. Крім того, необхідно зазначити, що із цього твердження вбачається майбутній принцип вільності та рівності людей у своїй гідності та правах, закріплений у статті 21 Конституції України: «Усі люди є вільні й рівні у своїй гідності та правах». Вільність та свобода - синоніми якісної фундаментальної філософської характеристики людської природи, вони є тотожними. Життя людини неможливе без соціуму, тому суспільний компонент ії природи невід’ємний від біологічного. Свобода завжди має об'єктивні межі залежно від історичних та соціальних умов. Але всі люди повинні мати рівні можливості реалізовувати таку «свободу» й не спричиняючи перешкод іншим. Тобто поводитись у суспільстві доречно щодо інших членів, зважаючи на панівні моральні та соціальні настанови.

Гідність людини - це її цінність як такої, самої по собі, котра не залежить від будь-яких індивідуальних біологічних або соціальних ознак. Це об'єктивна людська властивість, що відображає її унікальність. Стаття 28 Основного Закону України закріплює норму щодо права кожної людини на повагу до її гідності, тобто ніхто не може бути підданий катуванню, насильству, нелюдському або такому, яке принижує його гідність, поводженню чи покаранню. Жодна людина без її вільної згоди не може бути піддана медичним, науковим чи іншим дослідам. В іудейській релігійній традиції, зокрема в Талмуді, публічна образа (привселюдне приниження) вважається злочином та прирівнюється до кровопролиття. 
Стаття 24 Конституції України визначає, що громадяни мають рівні конституційні права і свободи та є рівними перед законом. Книга Вихід (Шмот, 12:49): «Один закон да буде і для природного мешканця, і для прийдешнього, котрий оселився між вами». Відповідно до вищевикладеного ідея цінності людини, незалежно від її приналежності до того чи іншого національного об’єднання, спочатку сформувалась в іудаїзмі.

Із єврейської релігійної традиції права та обов'язки людини не відділені та нерозривні, поєднуючись, вони сприяють тому, що людина має можливість виконувати Божий замисел повною мірою.

Таблиця 1

\begin{tabular}{|c|c|}
\hline Правова норма Конституції України & Релігійна норма іудаїзму \\
\hline $\begin{array}{l}\text { Стаття 24: «Громадяни мають рівні } \\
\text { конституційні права і свободи та є } \\
\text { рівними перед законом. Не може бути } \\
\text { привілеїв чи обмежень за ознаками } \\
\text { раси, кольору шкіри, політичних, } \\
\text { релігійних та інших переконань, статі, } \\
\text { етнічного та соціального походження, } \\
\text { майнового стану, місця проживання, за } \\
\text { мовними або іншими ознаками». }\end{array}$ & $\begin{array}{l}\text { Книга Вихід (Шмот, 12:49): «Один закон } \\
\text { да буде і для природного мешканця, і для } \\
\text { прийдешнього, який оселився між вами». }\end{array}$ \\
\hline $\begin{array}{l}\text { Стаття 27: «Кожна людина має } \\
\text { невід’ємне право на життя. Ніхто не } \\
\text { може бути свавільно позбавлений } \\
\text { життя. Кожен має право захищати } \\
\text { своє життя і здоров'я, життя і здоров’я } \\
\text { інших людей від протиправних пося- } \\
\text { гань». }\end{array}$ & $\begin{array}{l}\text { Глава 21:12-15 Книги Вихід (Книга Шмот): } \\
\text { «хто вдарить людину так, що вона загине, } \\
\text { да буде йому смерть», але якщо не було на- } \\
\text { міру вбити, але людина померла, то вбивці } \\
\text { надається місце, куди втекти. Шоста Божа } \\
\text { Заповідь також містить заборону вбивства } \\
\text { людини: «Не вбивай!». }\end{array}$ \\
\hline $\begin{array}{l}\text { Стаття 43: ««Кожен має право на пра- } \\
\text { цю, яке містить можливість заробляти } \\
\text { собі нажиття працею, що він вільно оби- } \\
\text { рає або на котру вільно погоджується». }\end{array}$ & $\begin{array}{l}\text { Книга Второзаконня (Дварим) }(24: 14,15): \\
\text { «Не притіняй найманого працівника зі сво- } \\
\text { їх братів або прийдешнього <...>. Віддавай } \\
\text { йому заробіток у той же день, ще до заходу } \\
\text { сонця, тому що він бідує й чекає свого заро- } \\
\text { бітку. Інакше він кличе до Господа, [жалію- } \\
\text { чись] на тебе, й на тобі буде гріх». } \\
\end{array}$ \\
\hline $\begin{array}{l}\text { Стаття } 45: \text { «Кожен, хто працює, має } \\
\text { право на відпочинок». }\end{array}$ & $\begin{array}{l}\text { «Шість день будеш робити діла свої, а сьо- } \\
\text { мого дня спочинеш, щоб відпочив віл твій, і } \\
\text { осел твій, і щоб відпочив син невільниці твоєї } \\
\text { і приходько», - Книга Вихід (Шмот) (23:12). }\end{array}$ \\
\hline $\begin{array}{l}\text { Стаття 51: «Повнолітні діти зобов’язані } \\
\text { піклуватись про своїх непрацездатних } \\
\text { батьків». }\end{array}$ & $\begin{array}{l}\text { Книга Дварим (5:16): «Поважай батька і } \\
\text { матір, як велів тобі Господь, твій Бог, щоб } \\
\text { подовжились твої дні і щоб добре було тобі } \\
\text { на землі, яку тобі дарує Господь, твій Бог». }\end{array}$ \\
\hline $\begin{array}{l}\text { Стаття } 53 \text { Конституції України: } \\
\text { «Кожен має право на освіту». }\end{array}$ & $\begin{array}{l}\text { Книга Дварим (5:28) закріплює не просто } \\
\text { право на навчання, а обов'язок навчатись } \\
\text { самому та навчати інших Божим заповідям, } \\
\text { одкровенням та мудрості. }\end{array}$ \\
\hline
\end{tabular}


Стаття 43 Конституції України закріплює право на працю, а отже, і право на заробітну плату, Книга Второзаконня (Дварим) (24:15) визначає обов'язок господаря оплачувати працю найманому робітнику в той самий день до заходу сонця.

Відповідно до статті 45 Конституції України кожен має право на відпочинок. Звертаємось до Четвертої Божої Заповіді, в якій ідеться про вшанування Суботи, шість днів для праці, а сьомий день - для Господа та відпочинку. «Шість день будеш робити діла свої, а сьомого дня спочинеш, щоб відпочив віл твій, і осел твій, і щоб відпочив син невільниці твоєї і приходько», - Книга Вихід (Шмот) (23:12).

Стаття 51 Конституції України містить норму щодо обов' язку дітей піклуватись про своїх батьків: «Повнолітні діти зобов’язані піклуватися про своїх непрацездатних батьків», відповідно до Книги Дварим (5:16), діти повинні поважати та шанувати своїх батьків, тобто, крім морального аспекту, мудреці тлумачили ще й матеріально забезпечувати непрацездатних батьків.

Стаття 53 Конституції України містить норму щодо отримання освіти. Звертаємось доКниги Дварим(Второзаконня), - цеп' ята частина П' ятикнижжя Мойсея, яка закріплює обов'язок єврейського народу вивчати Святе Письмо та навчати інших.

Висновки. Як бачимо, релігійна доктрина іудаїзму містить достатньо норм, котрі вплинули не лише на цивілізаційний розвиток людства, але й на майбутнє формування правових систем. Саме іудаїзм сформулював універсальну модель суспільної моралі, яка в подальшому стала фундаментальною основою для інших держав та народів. Правовий складник у релігійній доктрині іудаїзму є невідокремленим від її релігійної сутності та нерозривним із нею (табл. 1).

Єврейське право є феноменальним як з огляду порівняльного правознавства, так і завдяки гармонійному поєднанні релігійних приписів із нормами суспільної моралі та права, воно охоплює всі галузі правового буття людини, суспільства та держави. Варто зауважити переважання обов'язкових приписів перед дозвільними. Тобто обов'язок є головним та первинним, завдяки виконанню обов'язків однієї людини перед іншою й гарантується виконання прав та свобод один одного. Це є визначальною рисою іудейського права. Оскільки єврейське право грунтується на релігійних текстах, під час вивчення яких можна зробити не лише загальнотеоретичні, але і практичні висновки, котрі застосовуються до правового регулювання різних аспектів людського життя, воно потребує подальшого детального вивчення й може виступати предметом для наукових досліджень у майбутньому.

\section{Jimepamypa}

1. Біблія: переклад І.Огієнка. Київ : Українське біблійне товариство, 2002. 1165 с.

2. Бородин I. Генеза прав і свобод людини і громадянина. Юридичний вісник. 2010. № 3(16). C. $13-16$.

3. Илиев Р. Иудаизм и права человека. Свежий взгляд. URL: https://cyberleninka.ru/article/n/ iudaizm-i-prava-cheloveka (дата звернення: 10.02.2020).

4. Конституція України від 28.06.1996 р. № 254к/96-ВР. Дата оновлення: 01.01.2020. URL: https://zakon.rada.gov.ua/laws/show/254к (дата звернення: 10.02.2020).

5. Тора. Пятикнижие Моше. URL: https://nev-tanah.info/tora (дата звернення: 10.02.2020). 


\section{Анотація}

Тарановська А. О. Концептуальні основи прав і свобод людини в іудейському праві та їх сутнісні риси в Конституції України. - Стаття.

Висвітлене питання щодо актуальності теоретичного визначення категорії «права і свободи людини», зауважений самобутній характер єврейського права, що, можливо, здійснило історичний та цивілізаційний вплив на правові системи інших держав. Також досліджується процес формування концепції теорії прав і свобод людини в аспекті релігійної доктрини іудаїзму. Крім того, порівнюється та аналізується можливий вплив іудейської релігійно-правової системи на визнання категорії прав і свобод людини на офіційному рівні серед міжнародної спільноти та в національному законодавстві. Особлива увага приділяється дослідженню щодо закріплення фундаментальних прав і свобод людини, котрі беруть початок із релігійної традиції іудаїзму, в Основному Законі України. Автором визначено основні культурно-правові закономірності функціонування категорії «права людини» в контексті їх універсальності для суспільства.

Розглядаються основні аспекти релігійної традиції іудаїзму як стародавньої монотеїстичної релігії, яка зародилась на території Близького Сходу та об'єднує прихильників за етнічною ознакою.

У статті подана думка, що іудаїзм можна розглядати як першу релігію, котра закріпила універсальні норми моралі, яка змогла сформувати поведінку людини на буденному рівні, поєднуючи загальні та індивідуальні принципи впливу на суспільство. Іудейська релігійна доктрина розглядається як потужна система принципів, норм та приписів, котрі виступають універсальними суспільними регуляторами та мають чітку ієрархію. Автор зазначає важливість релігійних норм як соціальних важелів, які регулюють суспільні відносини, об’єктивно функціонують та впливають на життя суспільства. Проаналізовано сутність основних культурно-правових закономірностей функціонування концепції теорії прав і свобод людини в контексті релігійної правової системи й до сьогодення. Надано загальну порівняльну характеристику (у вигляді таблиці) норм Конституції України, котрі закріплюють визначені права та свободи людини, з релігійними текстами іудаїзму. Підсумовано, що є певний зв'язок між змістом іудейських релігійних норм та конституційними нормами Основного Закону України.

Ключові слова: права людини, іудаїзм, релігійно-правова система, конституційні права.

\section{Summary}

Taranovska A. O. Conceptual foundations of human rights and freedoms in Jewish law and their essential features in the Constitution of Ukraine. - Article.

This article discusses the relevance of the theoretical definition of the category of "human rights and freedoms", the distinctive nature of Jewish law, which may have exerted a historical and civilizational influence on the legal systems of other states. The process of forming the concept of the theory of human rights and freedoms in the aspect of religious doctrine of Judaism is also explored. In addition, the possible impact of the Jewish religious and legal system on the recognition of the category of human rights and freedoms at the official level among the international community and in national law is compared and analyzed. Particular attention is paid to the study on the consolidation of fundamental rights and freedoms of man, originating from the religious tradition of Judaism, in the Basic Law of Ukraine. The author defines the basic cultural and legal patterns of functioning of the category of "human rights" in the context of their universality for society.

The main aspects of religious traditions of Judaism are considered as ancient monotheistic religion, which originated in the Middle East and unites supporters on ethnic grounds.

The article shows that Judaism can be regarded as the first religion that consolidated universal norms of morality, which was able to form human behavior at the ordinary level, combining general and individual principles of influence on society. The Jewish religious doctrine is regarded as a powerful system of principles, norms and prescriptions that act as universal social regulators and have a clear hierarchy. The author notes the importance of religious norms as social levers regulating social relations, objectively functioning and influencing society. The essence of main cultural and legal patterns functioning of conception of human rights and freedoms in context of religious legal system and to the present is analyzed. The general comparative characteristic (in the form of a table) of norms of the Constitution of Ukraine, fixing the determined rights and freedoms of the person, with religious texts of Judaism is provided. It is concluded that there is a certain connection between the content of the Jewish religious norms and the constitutional norms of the Basic Law of Ukraine.

Key words: human rights, Judaism, religious-legal system, constitutional rights. 